\title{
Hadis Şerhleri Literatürüne Mütevazı Bir Katkı: Tek Hadis Şerhlerine Bir Giriş Denemesi*
}

\author{
Rıdvan Talha Yücedağ ${ }^{1}$
}

\begin{abstract}
$\ddot{\mathbf{O z}}$
Tek hadis şerhleri, “yalnızca bir hadis üzerine yazılan şerhler” olarak tanımlanır ve belirli sayıda hadisler üzerine yapılan şerhlerin en önemli türlerinden biridir. Tek hadis şerhleri, üzerinde yeterince çalışma yapılmamış bir alandır. Tespit edilebildiği kadarıyla tek hadis şerhleri üzerine sadece üç çalışma yapılmış olup bunların hepsi bibliyografik eserlerdir; tek hadis şerhlerinin tarihi ve yazılış amaçlarına dair bir eser bulunamamıştır. Bu durum, aynı zamanda bu alanda daha detaylı çalışmalar yapılmasının gerekliliğine işaret etmektedir. Her ne kadar hadis şerhlerinin tarihini inceleyen bir eser mevcut olmasa da, bibliyografik eserler üzerinden tek hadis şerhlerinin yüzyıllara göre artış ve eksilişi takip edilebilir ve bu artış ve eksiliş üzerinden bu şerhlerin tarihi hakkında bilgi edinilebilir. İlk örneğine 3./9. yüzyılda rastlanan tek hadis şerhleri, 8./14. yüzyılda çok yaygınlaşmış, 15./21. yüzyılda ise nicelik açısından zirveye ulaşmıştır. Tek hadis şerhlerinin telif sebepleri ise şahsî sebeplerden toplumsal tartışmalara kadar uzanan bir düzlemde büyük bir çeşitlilik arz etmektedir. $\mathrm{Bu}$ çeşitlilik aynı zamanda İslâmî ilimler tarihi boyunca âlimlerin eserlerini telif ederlerken hangi süreçlerden geçtiği hakkında da bir fikir vermektedir.
\end{abstract}

\section{Anahtar Kelimeler}

Hadis ilmi • Hadis şerhleri • Tek hadis Şerhleri • Hadis tarihi • Hadis literatürü • Sebeb-i telif

\section{A Contribution to Hadith Commentaries Literature: An Attempt of Introduction to Single Hadith Commentaries}

\begin{abstract}
Single hadith commentaries are defined as "commentaries that were written on a single, specific hadith" and they are one of the most important kinds of the commentaries written on a specific

* Bu çalışmanın aslı, İstanbul Şehir Üniversitesi İslami İlimler Fakültesine bitirme ödevi olarak sunulmuştur.

1 İstanbul Şehir Üniversitesi, Sosyal Bilimler Enstitüsü, Temel İslam Bilimleri Bölümü, 34865, Kartal/İstanbul. Eposta: ridvanyucedag@std.sehir.edu.tr
\end{abstract}


number of hadiths. It is observed that single hadith commentaries were highly neglected in the modern era. To the best of our knowledge, there are only three studies on single hadith commentaries all of which are bibliographic studies; none of these studies gives any information about the history and reasons for the compilation of this kind of commentaries. As much as being a starting point for this study, this situation constitutes an evidence for the necessity of further studies in this area. On the basis of the data taken from the bibliographic sources, it is possible to track the increase and decrease in the number of single hadith commentaries through centuries; and using this data, it is possible to deduce some information about their history. Single hadith commentaries, first of which was written in the $3^{\text {rd }} / 9^{\text {th }}$ century, were observed to be very prevalent in the $8^{\text {th }} / 14^{\text {th }}$ century, and reached their peak in quantity in the $15^{\text {th }} / 21^{\text {st }}$ century. In addition, the reasons for their compilation are so diverse that they span an area from individual reasons to the scholarly debates, which gives a clue to those who trace the process of producing scholarly works in the Islamic world throughout the history.

\section{Keywords}

The Science of hadith $\bullet$ Hadith commentaries $\bullet$ Single hadith commentaries $\bullet$ History of the science of the hadith $\bullet$ Hadith literature $\bullet$ Reasons for compilation

\section{مساهمة متواضعة في أدب تعليقات الحديث: تجربة مقدمة لتعليقات حديث واحد}

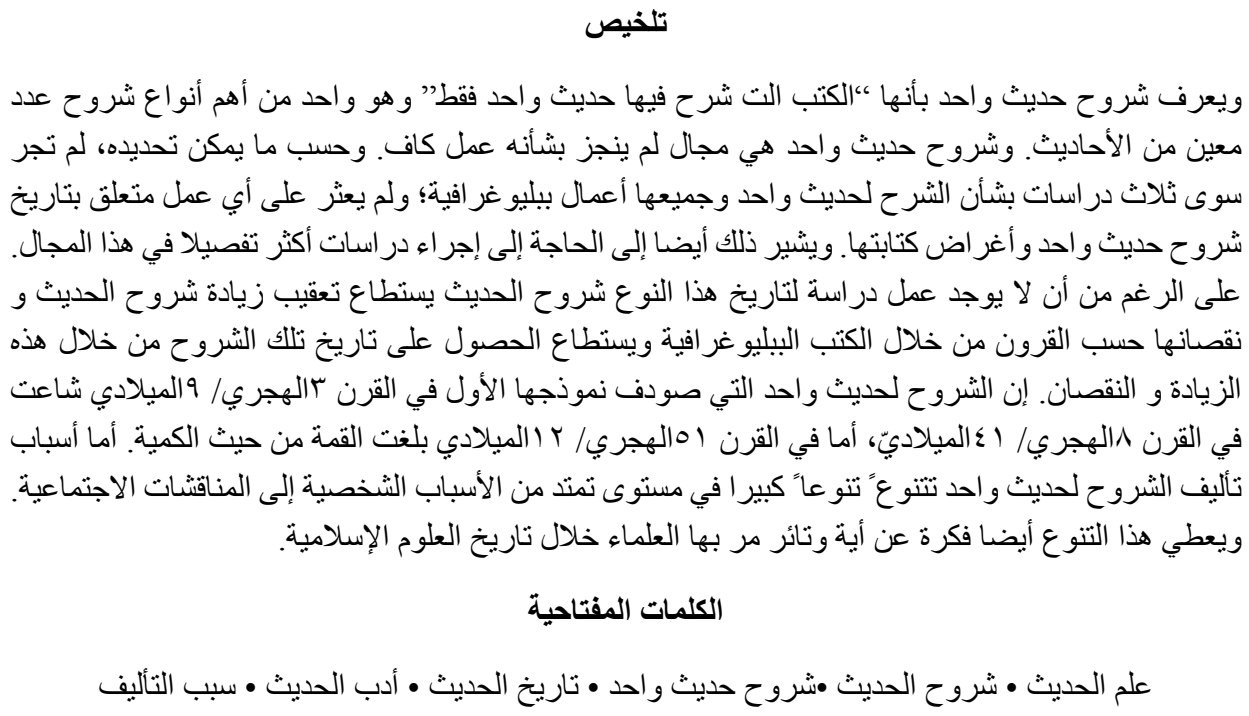

\section{Giriş}

Hz. Peygamber'in (s.a.v.) sünnetinin, tarih boyunca, hayatlarını nasıl yaşamaları gerektiği sorusuna cevap arayan Müslümanların Kur'ân-1 Kerîm'den hemen sonra 
başvurdukları ikinci kaynak olması hasebiyle, sünnetin malzemesi olan hadislerin doğru bir şekilde anlaşılması için çaba göstermek, Müslüman âlimler nezdinde bir zaruret ve vecîbe telakkî edilmiştir. Bundan dolayı, muhaddisler, hadisleri -belki hepsi günümüzde kullanılan manada "şerh" olarak isimlendirilemeyecek- çeşitli şekillerde anlama ve yorumlama gayreti içinde bulunmuşlardır. Bu gayretlerin en somut ve meşhur örnekleri, devasa hadis literatürünün önemli bir parçasını oluşturan hadis şerhleridir.

Genellikle belirli hadis kitaplarına bir bütün halinde yapılan şerhler şöhrete kavuştuğundan, "hadis şerhi”" denildiğinde akla ilk gelen kitaplar, bir hadis kitabı üzerine yazılan şerhlerdir. Bu tür şerhlerin daha yaygın olduğu doğrudur, ancak hadisleri şerh etme faaliyetinin bu kitaplarla sınırlı olduğu söylenemez. Zira bir kitabı baştan sona şerh eden eserler kadar muayyen bir sayıda hadis üzerine yazılan şerhler de mevcuttur. İslam tarihi boyunca birçok âlim tarafından telif edilen kırk hadis kitaplarına yazılan şerhler, yüz ve bin bir hadis şerhleri ile yalnızca bir hadis üzerine yazılan şerhler bu kapsamda değerlendirilebilir.

Yalnızca bir hadis üzerine yazılmış şerhlere günümüzde daha çok "tek hadis şerhleri” başlığı altında atıf yapılmaktadır. Bu başlıkla yapılmış çalışmalar da mevcuttur (Topaloğlu, 1998). Tek hadis şerhlerinin, diğer türler ile kıyaslandığında toplum nezdinde en az bilinen ve araştırmacılar tarafindan üzerine en az çalışma yapılan hadis şerhi türü olduğu söylenebilir. Birçok kişi tek hadis şerhleri literatürünün varlığından habersiz olup hadis şerhlerini, hadis kitapları üzerine yazılan şerhlerden ibaret zannetmektedir.

Tek hadis şerhleri üzerine yapılan çalışmalar, her ne kadar az olsa da, gün geçtikçe artmaktadır ${ }^{2}$ ve mevcut birikim, giriş mahiyetinde bir çalışma yapabilmek ve bu alanın önemini gösterebilmek için yeterli gözükmektedir. Bu çalışma hazırlanırken, tek hadis şerhleriyle ilgili telif edilen üç bibliyografik eserden istifade edilmiştir.

Tek hadis şerhleri üzerine yazılan bibliyografik eserlerin ilki Sadık Cihan'ın (1977) "Osmanlı Devrinde Türk Hadisçileri Tarafından Kırk Hadis Dışında Muayyen Sayıda Derlenen Hadis Mecmuaları ve Bir Hadis Üzerine Yazılan Risaleler" isimli makalesidir. Adından da anlaşılacağı üzere yazar, bu makalesinde hem kırk hadis dışında muayyen sayıla hadis ihtiva eden derlemeleri hem de tek hadis şerhlerini araştırma konusu edinmiştir. Yazar, bu küçük hacimli makalesinde yirmi bir tek hadis şerhinin yazarları, isimleri, basılmışlarsa nerede basıldıkları, basılmamışlarsa yazma nüshalarının yerleri hakkında bilgi vermiştir. Bu çalışma, tek hadis şerhlerinin tarihi yahut telif sebepleriyle ilgili hiçbir bilgi içermemektedir.

İkinci eser olan Nuri Topaloğlu'nun (1998) Tek Hadis Şerhleri adlı kitabı ise Cihan'ın makalesinin biraz daha geliştirilmiş hali olarak tavsif edilebilir. Kitabında yüz yetmiş

2 Taha Rıdvan Akay'ın 2019'da tamamlanan Osmanlı'da Tek Hadis Şerhçiliği: Kâfiyecî (879/1474) Örneği adlı yüksek lisans tezi tek hadis şerhlerinin tez seviyesinde çalışılan bir konu olmaya başladığını göstermesi açısından önemlidir. 
bir adet tek hadis şerhinin bibliyografik bilgilerini veren yazar, kitabına yazdığı kısa bir giriş ve sonuçta tek hadis şerhlerinin tarihi ve yazılış sebepleri hakkında muhtasar bilgiler vermiş, elde ettiği bilgileri istatistiklere dökerek bazı tespitlerde bulunmuştur.

Tek hadis şerhleri hakkında yazılmış en hacimli eser ise Yûsuf el-Atîk'in (1997) et-Ta 'rîf bimâ üfride mine'l-ehâdîși bi 't-tașnîf adlı kitabıdır. Atîk, bu kitabında sadece tek hadis şerhlerinin değil, konusu tek bir hadis olan bütün türlerdeki kitapların, ilgili oldukları hadislerin alfabetik sırasına göre bibliyografyasını çıkarmıştır. Bunu, sadece bir hadis üzerine müstakil bir kitap yazmanın gereksiz bir iş olmadığını ispatlamak, hala yazma halinde bulunan eserlerin tahkik edilmesini kolaylaştırmak ve hangi eserin tahkik edildiğini, hangisinin edilmediğini belirtip bir eserin ihtiyaç bulunmadığı halde birden çok kez tahkik edilmesini önlemek için yapmıştır (el-Atîk, 1997, s. 8). Yazarın mukaddimede verdiği bilgilere göre bu kitap, tek hadisler üzerine yapılacak geniş çaplı bir çalışmanın ilk adımıdır (el-Atîk, 1997, s. 6). Bundan dolayı, bu kitabın günümüze ulaşan bütün tek hadis şerhlerini kapsamadığı hatırda tutulmalıdır.

Tanıtılan üç eserin en büyük eksiği, tek hadis şerhleriyle ilgili yalnızca bibliyografik bilgiler vermeleri, bu eserleri analiz etmemeleridir. Zaten bu eserlerin müelliflerinin verileri tahlil etmek gibi bir amaçları yahut iddiaları da yoktur. Yalnız Nuri Topaloğlu, mezkûr kitabında bazı analizlerde bulunmuş, ancak bunu yüz yetmiş bir eser gibi küçük bir örneklem üzerinden gerçekleştirdiği için bu analizler tek hadis şerhleriyle ilgili genel bir çerçeve çizme konusunda yetersiz kalmıştır. Çalışmamızın amacı, kullandığımız kaynaklardaki bu eksiklikleri bir nebze de olsa gidermektir.

Bu çalışmada tek hadis şerhlerinin tarihî sürecinin tahlil edilebilmesi için bu şerhlerin sayılarının yüzyıllara ve müelliflere göre dağılımı verilmiş, bu bilgiler verilirken yukarıda zikredilen kaynaklar esas alınmıştır. Bu kaynaklar taranmış, kaynaklarda müelliflerin hakkında bilgi verdikleri eserlerin tamamını kapsayan bir liste oluşturulmuş ve bu listede eserler, müelliflere ve yüzylllara göre tasnif edilmiştir. Ancak söz konusu liste, hacmini çokça büyüteceğinden dolayı bu çalışmaya dâhil edilmemiştir. Esas alınan kaynaklarda mevzubahis edilen tek hadis şerhlerinden bazıları günümüzde matbu halde bulunurken bazılarının hala mahdut halde olduğu da okuyucuların dikkatine sunulmalıdır.

Bu üç eser, bu çalışmada en çok istifade edilen kaynakları oluşturmakla beraber diğer bazı kaynaklardan da istifade edilmiştir. Türkiye Diyanet Vakfi İslam Ansiklopedisi (kısaca DIA) bu kaynakların başında gelmektedir. Tek hadis şerhlerine dair liste oluşturulurken $D \dot{I} A$ 'daki muhaddis biyografilerinden ve müstakil maddelerde ele alınan hadis maddelerinden çokça yararlanılmıştır. Daha geniş çaplı bir çalışmada bu ansiklopedide yer alan muhaddis biyografilerinin ve müstakil maddelerde ele alınan hadislerin tamamı incelenip muhaddislerin eserleri ve hadisler üzerine yapılan çalışmalar arasındaki tek hadis şerhleri tespit edilebilir, bu işlem sonucunda tek hadis şerhlerinin sayısı hakkında daha kesin bir sonuca ulaşılabilir. Ayrıca, hadis fetvaları literatürü de tek 
hadis şerhleri konusunda zengin bir kaynaktır. Bu çalışmada, hadisler hakkında yazılan fetvalar tek hadis şerhleri olarak addedilip toplam sayıya dâhil edilmemiştir; çünkü hadis fetvalarından bazıları tek hadis şerhi sayılacak hacme ve muhtevaya sahipken, bazıları oldukça kısadır. Gelecekte yapılacak daha detaylı çalışmalarda bu literatür incelenerek hadis fetvaları kitaplarında yer alan tek hadis şerhi mahiyetindeki fetvalar da tespit edilip bu sayıya eklenebilir. Bu durumda tek hadis şerhlerinin sayısında büyük bir artış olacağına şüphe yoktur.

Yüzyıllar boyunca telif edilen eserlerle çok geniş bir hacme ulaşmış ve hala genişlemeye devam eden bir edebiyata mensup bütün eserleri tespit etmenin zorluğu araştırmacılar tarafından takdir edilecektir. Söz konusu edebiyat, hadis edebiyatının bir şubesi olduğunda bu tespit daha da zorlaşmaktadır; zira hadis edebiyatı, İslâmî ilimler edebiyatı içindeki en geniş edebiyatlardan biridir. Bundan dolayı, bu çalışma, yaklaşık on üç yüzyıldır telif edilen bütün tek hadis şerhlerini kapsadığı iddiasında değildir; eğer eldeki mevcut verileri etkili bir şekilde kullanarak tek hadis şerhleri literatürünün büyüklügünü ve önemini gösterebilirse başarıya ulaşmış olacaktır.

Bu çalışma, iki ana bölümden oluşmaktadır. Birinci bölümde, hadis şerhleri hakkında mukaddime sadedinde bilgiler verilecektir. Tek hadis şerhleri ile ilgili ikinci bölümde ise önce tek hadis şerhlerinin tarihi incelenecek, ardından âlimlerin neden tek hadis şerhleri telif ettikleri sorgulanarak tek hadis şerhlerinin telif sebepleri tespit edilmeye çalışılacaktır. Çalışma, sonuç kısmı ile nihayete erecektir.

\section{Hadis Şerhlerine Genel Bir Bakış}

Hadislerin söyleyenine nispetinin sıhhati ve anlaşılıp yorumlanmasıyla ilgili en temel kaynaklardan biri olması sebebiyle İslâmî ilimler geleneğinin vazgeçilmez bir parçası olma özelliği taşıyan hadis şerhleri, günümüzde tamamının bir kişi tarafından ihâta edilmesi mümkün olmayacak kadar geniş bir literatür olarak karşımıza çıkmaktadır. Bu bölümde, bu geniş literatür hakkında giriş mahiyetinde bilgiler verilecektir.

Hadislerin şerh edilmesi faaliyetinin izlerini Hz. Peygamber dönemine kadar sürmek mümkündür. Tabii ki bu dönem hadis literatürünün bir türü olarak şerhin başlangıç dönemi olarak kabul edilemez. Ancak sahâbîlerin Hz. Peygamber'in sözlerini ve fiillerini birbirlerine aktarmaları, aktarırken bunu birebir Hz. Peygamber'den duydukları lafızlar ile değil, mana ile yapmaları ve Hz. Peygamber'in hadislerini belirli olaylar üzerine rivâyet etmeleri, hadislerin yorumlanması faaliyetinin nüveleri sayılabilir (Türcan, 2011, s. 17). ${ }^{3}$ Bundan dolayı en azından hadis şerhlerinin oluşum sürecini bu dönemle başlatmak makul sayılabilir.

3 Hadis şerhlerinin tarihi ele alınırken, büyük oranda Zişan Türcan'ın Hadis Şerh Geleneği adlı kitabından istifade edilmiştir. Bununla birlikte, gerekli görüldüğ̈̈ yerlerde Türcan'ın bu tarih anlatısının ve dönemlendirmesinin sorunlu görülen bazı taraflarına dikkat çekilmiştir. 
Hadis şerhlerinin oluşum sürecinin ikinci aşamasının başlangıcı olarak ise hadislerin tedvin dönemi alınabilir. Hadisler, Emevî halifesi Ömer b. Abdülazîz'in (ö. 101/720) resmî tedvin emrine kadar çoğunlukla şifahi olarak aktarılıyordu. Bu dönemde daha çok -Hz. Peygamber döneminde de olduğu gibi- hadisleri "anlama" çabaları ön planda olmuştur. Hadislerin tedvin döneminde yazıya geçirilmesi ile ise hadisleri "yorumlama" faaliyeti başlamıştır (Türcan, 2011, s. 22).

Tedvinden kısa bir süre sonra (ya da onunla eşzamanlı olarak) başlayan tasnif dönemi ise hadis şerhlerinin oluşumunun üçüncü aşamasıdır. Tasnif faaliyetinin hadis şerhiyle ilişkisi, kendisini musannef kitapların bâb başlıklarında göstermektedir. Musannifler, kitaplarında hadisleri bâb başlıklarının altına dizmişlerdir, bu da belirli hadislerin yorumlanarak altına yerleştirildiği o bâb başlı̆̆ı ile ilişkilendirilmesi anlamına gelmektedir (Türcan, 2011, s. 22). Bu yorumlama faaliyetinin en bariz olduğu kitap, Buhârî'nin (ö. 256/870) el-Câmi 'u'ṣ-ṣahîh'idir (Blecher, 2018, pp. 62-63). Buhârî'nin bu yorumlama faaliyeti “Flkhu'l-Buhârî fì terâcimihî (Buhârî'nin fikhı bâb başlıklarındadır)." sözüyle de meşhur olmuştur. Kimi âlimler Buhârî'nin el-Câmi 'u'șșahîh'inin bâb başlıklarını inceleyen müstakil eserler de kaleme almışlardır (Uğur, 1996, s. 256 ve Kaynar, 2016, ss. 7-61).

Dördüncü aşama olarak ise garîbü'l-hadîs ilminin ortaya çıkışı kabul edilebilir. Kendisiyle ilgili müstakil eserlerin 2./8. yüzyılın ikinci yarısında telif edildiği görülen garîbü'l-hadîs ilminin başlangıcını -onunla ilk defa yoğun olarak ilgilenen kişilerin Şu'be b. el-Haccâc (ö. 160/776) ve Malik b. Enes (ö. 179/795) olduğu (Kandemir, 1996, s. 376) göz önünde bulundurulursa- 2./8. yüzyılın ilk yarısına kadar geri götürmek mümkün gözükmektedir. Garîbü'l-hadîs ile iştigal, hadislerdeki anlaşılması zor kelimelerin manalarının açıklanması anlamına geldiği ve bu açıklamalar, hadislerin anlaşılmasında ve yorumlanmasında ilk adım ve sistematik hadis şerhlerinin en önemli parçalarından biri olduğu için hadis şerhlerinin oluşumunun dördüncü aşaması olarak alınan bu aşama aynı zamanda bu sürecin son aşamasıdır.

Garîbü'l-hadîslerden sonra artık hadis şerhlerinin ilk örneklerini görmek mümkündür. Kendisi aynı zamanda bir garîbü'l-hadîs eseri sahibi olan Hattâbî'nin, Ebû Dâvûd'un Sünen'i üzerine yazdığı Me âlimü s-sünen ile Buhârî'nin el-Câmi 'u's-șahîhh'i üzerine yazdığ 1 A 'lamü's-sünen adlı şerhleri, hadis tarihinin ilk şerhleri kabul edilmektedir (Çakan, 2015, s. 189). Yaygın kabulün bu yönde olmasıyla birlikte, Hattâbî, bu şerhlerde söz konusu kitaplardaki hadislerin hepsini şerh etmediği ve sadece anlaşılması zor kelimelerin manaları ile hadislerden çıkan fikhî ahkâma yer verdiği için bu eserler, kimi müellifler tarafindan "şerh" olarak isimlendirilmemiş, garîbü’l-hadîs ile hadis şerhleri arasında bir geçiş mahiyetinde eserler olarak telakki edilmiştir (İbnü’l-Esîr, 1969, s. 45). Ayrıca, Hattâbî'den önce yaşayan İbnü's-Serh'in (ö. 250/864) Şerḥu'l-Muvaț̣a' (Sandıkç1, 1991, s. 325), Yahyâ b. Zekeriyyâ b. Müzeyn'in (ö. 259/872) Tefsîru'lMuvațta' (Kettânî, 1994, s. 8), ve el-Bezzâr'in (ö. 292/905) Şerḥu Muvațta'i Mâlik 
(Sandıkçı, 1991, ss. 184-185) adlı eserlerinde İmam Mâlik'in Muvațta 'ını şerh ettikleri de kaynaklarda geçen bilgiler olarak karşımızda durmaktadır. Bu bilgilerin doğru olması durumunda ilk hadis şerhinin telif tarihini hicrî üçüncü yüzyılın ilk yarısına kadar geri götürmek mümkün olacaktır.

Hattâbî ile başlatılan hadis şerhleri tarihi kabaca iki kısma ayrılmaktadır. Birinci kısım, Hattâbî’nin şerhlerini yazdığı dönemden Yahyâ b. Şeref en-Nevevî’nin (ö. 676/1277) Müslim b. el-Haccâc'ın (ö. 261/875) el-Müsnedü'ș-ṣahîh isimli eseri üzerine yazdığı şerhe kadar olan dönemdir. Bu dönemde yazılan şerhlerde garîbü'l-hadîs ile beraber özellikle hadislerden çıkan fikhî hükümlerin, bu şerhlerin karakteristiğini belirleyecek yoğunlukta bulunmasından dolayı, bunlar "fikhî şerhler" olarak isimlendirilmiştir (Türcan, 2011, s. 54).

İkinci kısım ise Nevevî’nin el-Müsnedü'ṣ-șahîhh üzerine yazdığı şerhten sonraki dönemde telif edilen eserlerdir. Bunlar, hadisleri sadece garîbü'l-hadîs ve fikhu'l-hadîs açılarından değil, şekil ve içerikle ilgili neredeyse bütün açılardan inceledikleri için "zengin içerikli şerhler" olarak isimlendirilmiştir (Türcan, 2011, s. 197). Bu dönemdeki hadis şerhlerinin en meşhurları İbn Hacer el-Askalânî’nin (ö. 852/1449) ve Bedruddîn elAynî’nin (ö. 855/1451), Buhârî’nin el-Câmi 'u'ș-șahîh'i üzerine yazdıkları Fetḥu'l-Bârî ve 'Umdetü' l-kârî adlı şerhleridir. Bu şerhler, birçok âlim tarafindan hadis şerhlerinin en mükemmelleri kabul edilmiştir. Öyle ki, kimi âlimler bu şerhlerden sonra Buhârî’nin kitabı üzerine şerh yazılmasına gerek kalmadığını düşünmüşlerdir. Buna Şevkânî'nin (ö. 1250/1834) bir sözü örnek olarak verilebilir. Bir gün öğrencileri, Şevkânî’ye, "Buhârî'nin el-Cami 'ini şerh etseniz ne güzel olur." demişler, o da Hz. Peygamber'in bir hadisine telmihte bulunarak ve İbn Hacer'in Fethu'l-Bârî'sini kastederek "Fetihten sonra hicret yoktur.” diye cevap vermiştir (el-Kannevcî, t.y., s. 132).

Zengin içerikli şerhlerin muhtevasında en sık rastlanan bilgiler şu konulara dairdir: Hadislerin tahrîci, senedlerde yer alan râvîlerin tanıtımı, hadislerin sıhhat derecesinin tespiti, hadislerin lügat ve dil ilimleri açısından incelenmesi, hadsilerden çıkan hükümler ve hadisler arasında görülen ihtilafların çözümü (Efendioğlu, 2010, s. 560).

Hadis şerhleri tarihini "fikhî şerhler" ve zengin içerikli şerhler" şeklinde bir dönemlendirmeye tabi tutmak hadis şerhlerinin geneline bakıldığında uygun gözükse de bu tasnife uymayan bazı şerhler de vardır. Mesela, İbn Abdilber'in (ö. 463/1071) İmam Mâlik' in Muvatța' ina yazdığı iki büyük şerh olan et-Temhîd ve el-İstižkâr, İmam Nevevî'nin, İmam Müslim'in el-Müsnedü 'ṣ-șahîh'ine yazdığı şerhten yaklaşık iki yüz sene önce telif edilmesine rağmen zengin içerikli şerhlerin özelliklerini taşımaktadır.

Hadis şerhleri telif geleneği yüzyıllar boyunca sürmüştür ve hala devam etmektedir. Bu bağlamda, âlimlerin hadis şerhleri literatürüne yaptı̆̆ı katkılar yadsınamaz. Ancak, her ne kadar âlimler tarafindan hadis şerhleri literatürüne büyük katkılar yapılmış olsa da hadisleri şerh etme ameliyesinin nazariyat dair bu kadar geniş bir edebiyat 
oluşmamıştır. Bunun muhtemel sebepleri arasında hadis âlimlerinin hadis şerhini ayrı bir ilim olarak görmemiş; hadis şerhlerini cerh ve tadil, nâsih ve mensûh, garîbü'l-hadîs ve fikhu'l-hadîs gibi diğer hadis ilimlerinin mezcedildiği kitaplar olarak değerlendirmiş olma ihtimalleri zikredilebilir. 14./20. yüzylla gelindiğinde ise hadis şerhinin artık müstakil bir ilim olarak ele alınma çabaları göze çarpar. Tespit edilebildiği kadarıyla mezkûr yüzyıldan itibaren yapılan çalışmalarda hadis şerhi, "hadis şerhi ilmi ( 'ilmu şerhi 'l-ḥadîs.s)" (el-Kannevcî, 1978, s. 336), "hadis şerhleri ilmi ( 'ilmu şurûhi 'l-ḥadîs_s)", "hadislerin tevili (te'vîlü'l-hadîs_)", "hadislerin anlaşılması (fikhu'l-hadîs_.s", "hadisten çıkan manalar ilmi ( 'ilmu me 'âni'l-hadîss)", "hadisleri açıklama usulü ilmi ('ilmu ușûli tefsîri'l-hadîs_)" (Bâzmûl, 2009, s. 7) olarak isimlendirilmiş ve hadis ilimlerinin bir kısmı olarak incelenmiştir.

Hadis şerhleri hakkındaki bu kısa bilgilendirmeden sonra onun bir alt dalı olan tek hadis şerhleri incelenebilir.

\section{Tek Hadis Şerhleri}

"Hadis şerhi” denildiğinde akla ilk olarak bir hadis kitabı üzerine yazılan şerhlerin gelmesi ve çoğu kişinin hadis şerhleri literatürünü sadece bu kitaplarla sınırlamasının yaygın bir problem olduğuna daha önce değinilmişti. Bu durumun bir problem olması, hadis literatürü içinde bu şerhlerin yanında, bin bir hadis, yüz hadis ve kırk hadis şerhleri gibi belirli sayıda hadisler üzerine yazılmış şerhlerin de mevcut olması (Ünver, 1986, s. 438) ve âlimlerin bu tür şerhlere de büyük bir önem atfetmiş olmalarıdır. "Yalnızca bir hadis üzerine yazılmış şerhler" olarak tanımlayabileceğimiz tek hadis şerhleri de yüzyıllar boyunca birçok âlimin ihtimamına mazhar olmuştur.

Tek hadis şerhlerine hasredilen bu bölümün ilk kısmında, telif edilen tek hadis şerhi sayılarının yüzyıllara göre dağılımı verilerek bu şerhlerin tarihiyle ilgili bazı çıkarımlarda bulunulacaktır. İkinci kısımda ise tek hadis şerhlerinin en yaygın telif sebepleri tespit edilmeye çalış1lacaktır.

\section{Tek Hadis Şerhlerinin Tarihi}

Belirli bir hadis üzerine yazılan şerhler, bir hadis kitabı üzerine yazılan şerhlerle tarihin her döneminde yan yana bulunmuştur, ancak -belki de hacminin küçüklüğünden dolayı- ihmal edilmiştir. Hadis şerhi edebiyatını çalışan araştırmacılar, bir kitap üzerine yazılan şerhleri çalışmışlar ve hadis şerhleri tarihini bu kitaplar üzerinden yazmayı tercih etmişler, tek hadis şerhlerini genellikle göz ardı etmişlerdir. Fakat tarih boyunca telif edilen tek hadis şerhlerinin sayısı incelediğinde, bu sayının bu ihmali hak etmeyecek denli büyük bir yekûn tuttuğu görülmektedir. 
Bu bölümde, 3./9. yüzylldan günümüze kadar telif edilen tek hadis şerhleri incelenerek hangi yüzyıllarda ne kadar tek hadis şerhi yazıldığı, en çok hadis şerhi telif eden müellifler ve üzerine en çok tek hadis şerhi yazılan hadisler tespit edilecektir.

Günümüze dek yapılan bibliyografya araştırmaları sonucunda ulaşılabilen tek hadis şerhleri yüzyıllara göre düzenlendiğinde Tablo 1'deki sonuçla karşılaşılmaktadır. Tabloda toplam dört yüz otuz üç adet tek hadis şerhine ulaşıldığı görülmektedir. Yalnızca bu sayı bile, tek hadis şerhleri literatürünün oldukça zengin bir literatür olduğunu göstermek için yeterli bir delil sayılabilir.

3./9. yüzyıldan sonra tek hadis şerhlerinin sayısında görülen artış, 8./14. yüzyılda altmış üç şerh ile zirveye ulaşmıştır. Bu yüzyıldan sonra telif edilen tek hadis şerhlerinin sayısı, 15./21. yüzyıla kadar bu sayıya ulaşamayacaktır. 8./14. yüzyıldaki bu artışın en büyük iki sebebi, bu literatüre büyük katkılarda bulunan iki velûd âlimdir. Bu yüzyılda telif edilen tek hadis şerhleri incelendiğinde, İbn Teymiyye (ö. 728/1328) ile İbn Receb el-Hanbelî’nin (ö. 795/1393) bu literatüre olan katkıları hemen fark edilmektedir. İbn Teymiyye on sekiz, İbn Receb ise yirmi tek hadis şerhi telif etmişlerdir ki bu ikisinin toplamı, bu yüzyılda yazılan tek hadis şerhlerinin yarısından fazladır. Bu müelliflerin bazı eserlerini neden telif ettikleri ilerleyen bölümlerde incelenecektir, ancak genel olarak 8./14. asırda neden bu kadar çok tek hadis şerhi telif edildiği ayrıca araştırılmaya muhtaçtır. Bu dönemde şerhçiliğin oldukça gelişmiş olması, şerh yazmanın muhaddisin ilmini ve sanatını göstermesinin yollarından biri haline gelmesi, toplumda tartışılan meselelerin tek hadis şerhleri üzerinden yansıtılma çabası muhtemel sebepler arasında zikredilebilir.

Bir hadis kitabı üzerine yazılan şerhlerin en mükemmel örneklerinin verildiği 9./15. yüzyılda ise otuz sekiz adet tek hadis şerhi telif edilmiştir. Önceki yüzyıla nispetle görülen bu azalışın akla gelen ilk sebebi bu yüzyılda yazılan Fetḥ'l-Bârî ve 'Umdetü'l-kârî gibi şerhlerin, kendilerinden önceki literatürü ele alıp, harmanlayıp, en güzel şekilde bir araya getirmesinden dolayı, artık bu kitaplarda şerh edilen hadislerin -en azından o yüzyılda- ayrıca şerh edilmesine gerek kalmaması olabilir. Gerçekten de bu yüzyılda en çok tek hadis şerhi yazan müelliflerin Fetḥu'l-Bârî̀nin sahibi İbn Hacer el-Askalânî (ö. 852/1449), onun öğrencisi Şemseddin es-Sehâvî (ö. 902/1497) ve Mısır'da yaşayan bu âlimlere çok da uzakta olmayan Şam'da yaşayan, dolayısıyla İbn Hacer'in şerhinden haberdar olmaması pek de muhtemel olmayan İbn Nâsırüddin ed-Dımeşkî'dir (ö. 842/1438). Yani bu yüzyılın tek hadis şerhi yazarları, İbn Hacer'in şerhinden haberdar olan âlimlerdir ve onların müstakil eserlerde şerh ettikleri hadislerin çoğunun Buhârî’nin kitabında tahrîc etmediği ve dolayısıyla bu asrın büyük şerhlerinde bulunmayan hadisler olduğu söylenebilir. Bu da, eğer bu dönemde Fethu'l-Bârî ve 'Umdetü'l-kârî gibi büyük eserler telif edilmeseydi, tek hadis şerhleri yazmaya daha çok ihtiyaç olacağı yönündeki kanaati kuvvetlendirmekte ve bu kitapların önemini bir kez daha gözler önüne sermektedir. 
14./20. yüzyılda telif edilen tek hadis şerhleriyle ilgili bir husus burada zikredilmelidir. $\mathrm{Bu}$ çalışmaya, müelliflerin müstakil bir kitap yahut risale olarak telif ettikleri eserler alınmıştır. Osmanlı Devleti'nin meşrutiyet döneminde yayımlanan Sebîlürreşâd, Sırât-ı Müstakim ve Cerîde-i Sûfiyye gibi bazı dergilerde genellikle "Bir Hadis-i Şerif” başlığı altında yahut mevzubahis hadis direkt başlığa taşınarak bazı hadisler tercüme ve şerh edilmiştir (Ceyhan, 1991). Bu bir iki sahîfelik şerhlerde, genelde hadisteki kelimelerin manaları verilmiş, hadisin nasıl anlaşılması gerektiğinden ve Müslümanların o hadisi hayatlarına nasıl tatbik etmeleri gerektiğinden bahsedilmiştir. Fakat bu eserlerin hacimleri çok küçük olduğundan bunlar bu çalışmanın kapsamına dâhil edilmemiştir.

En çok tek hadis şerhi telif edilen yüzyıl ise doksan sekiz şerh ile içinde bulunduğumuz 15./21. yüzyıldır. Bu yüzyılın henüz yarısı bile tamamlanmamışken bu kadar çok tek hadis şerhinin yazılması, 16./22. yüzyıla kadar bu sayının daha da artacağı şeklinde yorumlanabilir. Özellikle günümüzde çokça görülen, "hadisleri anlamada yöntem"i konu edinen, içinde yaşadığımız asırda hadislerin nasıl anlaşılması gerektiğine dair metot denemeleri olan çalışmaların sayısı artmaktadır. Bu çalışmalarda yazarlar, teklif ettikleri yöntemin makul bir yöntem olduğunu ispatlamak için bir hadis üzerinde bu yöntemi uygulamaktadırlar. Böylece ortaya tek hadis şerhleri çıkmaktadır.

\begin{tabular}{|c|c|}
\hline \multicolumn{1}{|c|}{ YÜZYIL } & TEK HADIS ŞERHI SAYISI \\
\hline 3./9. Yüzyll & 3 \\
\hline 4./10. Yüzzyl & 8 \\
\hline 5./11. Yüzyll & 7 \\
\hline 6./12. Yüzyyl & 12 \\
\hline 7./13. Yüzyll & 19 \\
\hline 8./14. Yüzyll & 63 \\
\hline 9./15. Yüzyll & 38 \\
\hline 10./16. Yüzyyl & 31 \\
\hline 11./17. Yüzyyl & 21 \\
\hline 12./18. Yüzyll & 39 \\
\hline 13./19. Yüzyyl & 36 \\
\hline 14./20. Yüzyll & 58 \\
\hline 15./21. Yüzyyl & 98 \\
\hline TOPLAM & 433 \\
\hline
\end{tabular}

Tablo 1 Tek Hadis Şerhi Sayılarının Yüzyıllara Göre Dağılımı

En çok tek hadis şerhi telif eden müelliflere bakıldığında ise Tablo 2'deki gibi bir manzarayla karşılaşılmaktadır. Buna göre en çok tek hadis şerhi telif eden âlim yirmi tek hadis şerhiyle İbn Receb el-Hanbelî olmuştur. Onu, on sekiz şerhle İbn Teymiyye takip etmektedir. Bu iki âlimin de 8./14. yüzyılda yaşadığı zikredilmişti. Bu âlimlerin neden bu kadar çok şerh yazdıkları sorgulanıp hayatları incelendiğinde, özellikle İbn Receb'in genel olarak hadisleri şerh etmeye büyük ihtimam gösterdiği görülmektedir. Zira kendisi Tirmizî'nin (ö. 279/892) el-Câmi ine bir şerh yazmış, Cami u'l- 'ulûm ve'l-hikem adlı eserinde Nevevî'nin meşhur el-Erba '̂̂n'unu esas alarak cevâmi‘u'l-kelim özelliğine 
sahip elli hadisi şerh etmiş, ayrıca Buhârî'nin el-Câmi 'u’ṣ-șaḥ̂hh'ini de şerh etmeye başlamış ancak bitirememiştir (Kallek, 1999, s. 245). Bu durum göz önüne alındığında, tek hadis şerhlerinin İbn Receb için Buhârî’nin ve Tirmizî’nin kitapları gibi büyük hadis kitaplarını şerh etmeden önceki bir hazırlık aşaması olduğu tahmininde bulunulabilir; İbn Receb, kendi hadis şerhçiliğini geliştirmek için işe tek hadis şerhlerinden başlamış, daha sonra hacimli eserleri şerh etmiş olabilir. İbn Teymiyye'nin ise selefî düşünceyi canlandırdığı bilinen bir gerçektir. Bunu yaparken ortaya koyduğu görüşleri hadisleri şerh ederek desteklemek istemiş olması muhtemeldir.

En çok şerh edilen hadisler ise niyet hadisi (el-Buhârî, 2017, s. 191) ile Ümmü Zer‘ hadisidir (el-Buhârî, 2017, s. 1298). Niyet hadisine dair on sekiz, Ümmü Zer` hadisine dair ise on yedi şerh tespit edilebilmiştir. Neden özellikle bu hadislerin şerh edildiği bir sonraki kısımda ele alınacaktır.

\begin{tabular}{|c|c|c|}
\hline MÜELLIF & $\begin{array}{c}\text { TEK HADIS } \\
\text { ŞERHİ SAYISI }\end{array}$ & YÜZYIL \\
\hline İbn Receb el-Hanbelî & 20 & 8./14. Yüzyıl \\
\hline Takıyyüddin b. Teymiyye & 18 & 8./14. Yüzyıl \\
\hline Ahmed b. Muhammed b. es-Siddîk el-Gumârî & 17 & 14./20. Yüzy1l \\
\hline Muhammed b. Ali eş-Şevkânî & 13 & 13./19. Yüzy1l \\
\hline Şemseddin es-Sehâvî & 12 & 9./15. Yüzyıl \\
\hline Celâleddin es-Süyûtî & 11 & 10./16. Yüzy1l \\
\hline Emîr es-San'ânî & 9 & 12./18. Yüzy1l \\
\hline İbn Nâsırüddin ed-Dimeşkî & 8 & 9./15. Yüzy1l \\
\hline Ebû Bekir İbnü’l-Arabî & 7 & 6./12. Yüzyıl \\
\hline Muhammed Murtazâ ez-Zebîdî & 6 & 12./18. Yüzy1l \\
\hline
\end{tabular}

Tablo 2 En Çok Tek Hadis Şerhi Telif Eden on Müellif

\section{Tek Hadis Şerhlerinin Telif Sebepleri}

On üç yüzyıl boyunca yüzlerce tek hadis şerhi telif edildiği düşünüldüğünde, bunların hepsini kapsayacak birkaç telif sebebi zikretmenin imkânsız olduğu anlaşılacaktır. Tek hadis şerhleri, şârihlerin şahsi isteklerinden toplumdaki ilmî tartışmalara varıncaya kadar birçok farklı sebepten ötürü telif edilmiştir. Bundan dolayı, şerhlerin telif sebeplerini belirli birkaç maddeye hasretmek ne mümkün ne de mantıklı gözükmektedir.

Bu bölümde, tek hadis şerhlerinin tespit edilebilen en yaygın telif sebepleri zikredilip bunlara en az birer örnek verilecektir. Böylece bu zengin literatürün nasıl oluştuğuna dair bir fikir edinilecektir. 
Bir âlimden bir hadisin şerh edilmesinin istenmesi. Tek hadis şerhlerinin telif sebeplerinin en yaygınlarından biri, öğrencilerinin, hocalarından bir hadisi şerh etmelerini istemeleridir.

Bu sebeple telif edilen tek hadis şerhlerine örnek olarak Kadı İyâz'ın (ö. 544/1149) Buġyetü'r-râid limâ teżammeneĥ̂ hadîsü Ümmi Zer' mine'l-fevâid adlı eseri zikredilebilir. Kadı İyâz, bu eserini, bir öğrencisinin kendisinden Ümmü Zer' hadisini şerh etmesini istemesi üzerine telif etmiştir. Kendisi, kitabının mukaddimesinde şöyle demektedir (Kadı İyâz, 1975, s. 1):

Allah senin başarını daim etsin ve sana doğru yolu göstersin, Ümmü Zer‘ hadisinin manalarının ve maksatlarının anlaşılmayanlarını tefsir etmem ve kapalı kalmış lafızlarının kilitlerini açmam konusunda bana sorduğun soruyu gördüm. Bunun üzerine sorunu doğru bir şekilde cevaplama konusunda yardımı ve başarıyı Allah’tan dileyerek sorduğun soruyu cevaplamaya koyuldum.

Ümmü Zer` hadisi uzun bir hadistir ve anlaşılması zor birçok kelime ile birçok edebî sanat ihtiva etmektedir. Kadı İyâz’ın, "manaların ve maksatların anlaşılmayanları” ile "lafızların kilitleri” ibarelerinden kastı bu olmalıdır. Bu durum, Ümmü Zer' hadisin çokça şerh edilmesinin sebepleri arasında zikredilebilir.

Burada, bir âlimden bir hadisin şerh edilmesinin istenmesinin, eserlerin telifi için her zaman gerçek bir gerekçe olmayabileceğini not etmek yerinde olacaktır. Gerçekte böyle bir talep olmasa bile asırlar boyunca birçok âlim kitabına bu kalıbı kullanarak başlamayı bir âdet haline getirmiştir. Bundan dolayı bu tür telif sebepleri incelenirken dikkatli olunmalıdır.

Bir âlime bir hadisle ilgili soru sorulması. Bir âlime bir hadisle ilgili soru sorulması da o âlimin o hadisi şerh etmesinin en çok rastlanan sebeplerinden biri olmuştur. Soruyu, âlimin öğrencileri yahut halktan biri sorabilmektedir ve soru, hadisin farklı yönleriyle ilgili olabilmektedir. Mesela, bazen hadisin manasına dair sorular sorulurken, bazen de hadisin irabıyla ilgili sorular sorulmuştur. Müellifler de bazı durumlarda sadece sorulan soruya cevap vermekle yetinirken, bazı durumlarda soruda geçmeyen konularla ilgili açıklamalar da yapmışlardır; bu da yazılan şerhlerin hacminin büyümesine sebep olmuştur.

Mezkûr telif sebebine sahip olan tek hadis şerhlerinden biri Kemâleddin İbnü'lHümâm'ın (ö. 861/1457) I'râbu kavlihî kelimetâni hafîfetâni 'ale'l-lisân adlı eseridir. İbnü'l-Hümâm, bu eseri, bir kadının ona bu hadisle ilgili soru sorması üzerine telif etmiştir. Kendisi, eseri neden yazdığını şöyle açıklamaktadır (Kemâleddin İbnü'lHümâm, 2011, ss. 17-18):

Yanıma bir kadın geldi. Elinde, onu kendisine bir adamın verdiğini ve içindeki soruya cevap istediğini söylediği bir kâğıt vardı. Kâğıda baktım, içinde Hz. Peygamber'in 


$$
\text { كلمتان خفيفتان على اللسان، تقيلتان في الميزان، حبييتان إلى الرحمن: سبحان الله وبحمده سبحان الله العظيه. }
$$

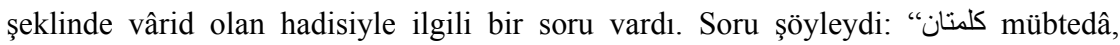
سبحان الله hözünün mübtedâ olduğunu söyleyenlerin görüşü mü doğrudur, yoksa سبحان الله nasb üzere mebnî olduğu için bu görüşü reddedenlerin görüşü mü doğrudur? Bu hadiste birden çok haber mi vardır?” Bu fakir kul da bilgisinin eksikliğine ve zamanının darlığına rağmen şunları söylemiştir...

Burada sorunun, bir öğrenci tarafından değil, yabancı bir kadın tarafından sorulduğu görülmektedir. Hatta İbnü'l-Hümâm'ın sözlerinden anlaşıldığına göre soruyu soran, kadının kendisi değil, kadına sorunun yazılı olduğu kâğıdı veren kişidir. O kişinin soruyu neden kendisinin sormadığı merakı celb edicidir. Ayrıca sorunun hadisin irabıyla ilgili olduğu görülmektedir. Fakat soru "Bu hadisin irabı nedir?” şeklinde genel olarak değil, kelimelerin irapları hakkındaki ihtilaflara değinilerek ayrıntılı bir şekilde sorulmuştur ki bu da soruyu soran kişinin ilim ehli biri olduğu izlenimini uyandırmaktadır. Bundan dolayı da İbnü'l-Hümâm, eserde sadece hadisin irabına odaklanmış, hadisle ilgili diğer meseleler hakkında konuşmamıştır.

$\mathrm{Bu}$ duruma bir başka örnek de Ahmed b. Alî İbn Hacer el-Askalânî’nin Cüz'ün fi'l-kelâmi 'alâ kavlihî inne'mraetî lâ teruddü yede lâmis adlı cüzüdür. İbn Hacer, bu cüzü, kendisine sorulan bir soru üzerine yazmıştır, ancak soruyu kimin sorduğunu belirtmemiştir. Kendisi, cüze şöyle başlamıştır (el-Askalânî, 2015, s. 31):

$$
\begin{aligned}
& \text { hadisi hakkında bana bir soru } \\
& \text { soruldu. Soru şöyleydi: "Bu hadisin durumu nedir? Bu hadisi kimler rivâyet etti? } \\
& \text { Metninin geri kalanı nasıldır? Bu hadisin manası nedir? Bu hadis hakkında kimler } \\
& \text { görüş belirtmiştir? Hadisteki erkekle kadının isimleri biliniyor mu? Hadisteki لا أستطيع } \\
& \text { kelimesinin manası nedir?” Ayrıca cevabın uzun olması istendi. }
\end{aligned}
$$

Görüldüğü gibi İbn Hacer'e hadisin hem rivâyet durumu hem de muhtevâsına dair sorular yöneltilmiştir. Soruda cevabın uzun olmasının istenmesine de dikkat edilmelidir. Soruyu soran kişi İbn Hacer'in kısa bir cevapla yetinmesini istememiş, ondan uzun ve ayrıntılı bir cevap istemiştir. Bu, 9./15. yüzyıl insanının şerh anlayışına da 1şık tutması muhtemel bir istektir. İnsanlar, hadisleri her yönleriyle, ayrıntılı bir şekilde şerh eden eserler istemektedirler. Bununla beraber, İbn Hacer'in bu eseri, (adının "cüz" olmasından da anlaşılacağı üzere) o kadar da hacimli değildir, matbu nüshada on iki sayfa tutmaktadır.

Bir soru üzerine telif edilen bir diğer önemli tek hadis şerhi de İbn Teymiyye'nin Su'âlün fî hadîși’n-nüzûl ve cevâbuhû adlı eseridir. Adından da anlaş1labileceği üzere İbn Teymiyye bu eserde Hz. Peygamber'in Allah'ın dünya semasına nüzul ettiğini söyleyen hadisini (el-Buhârî, 2017, s. 413), kendisine bu hadis hakkında bir soru sorulması üzerine şerh etmiştir. Aslında soru bir fetva talebi şeklinde gelmiştir. İbn 
Teymiyye'den fetva isteyen kişi, nüzul hadisi hakkında tartışan -biri hadisi kabul eden, diğeri de reddeden- iki kişi arasında geçen diyaloğu aktarmış, bunlardan hangisinin haklı olduğunu sormuş ve ondan bu konudaki şüpheleri izale etmesini istemiştir (İbn Teymiyye, 1993, ss. 67-68). İbn Teymiyye de bu hadisi tafsilatlı bir şekilde şerh etmiştir.

Hadisin önemli görülmesi. Bazı hadislere âlimler tarafindan özel bir önem atfedilmiştir ve bu hadislerin herkes tarafından bilinmesi ve anlaşılması için büyük bir çaba harcanmıştır. Bu hadislere en iyi örnek niyet hadisidir. Birçok muhaddis ve fakih, bu hadisin İslam'ın esaslarından biri olduğunu söylemiştir. İmam Şâfi' ‘̂̀’nin (ö. 204/820) şu sözü çok meşhurdur: 'İlmin üçte biri ‘Ameller, niyetlere göredir.' hadisinin içinde saklıdır” (es-Süyûtî, 1998, s. 55). Ayrıca müellifler, önemine binâen kitaplarına bu hadisle başlamayı âdet edinmişlerdir. Özellikle hadis literatürünün en muteber kitabı olan Buhârî'nin el-Câmi 'u'ṣahîh'inin bu hadisle başlaması, ondan sonraki muhaddislerin ve diğer âlimlerin de kitaplarına bu hadisle başlamalarında müessir olmuştur. Bu sebeplerden dolayı bu hadis üzerine birçok şerh yazılmıştır. Bunlara örnek olarak Celâleddin es-Süyûtî'nin Müntehe'l-âmâl fí şerḥi hadîși inneme'l-a 'mâl ve Osmanlı âlimlerinden Ahmed Çelebi’nin (ö. 927/1520) Risâle fì şerhi hadî̀isi inneme'la'mâlü bi'n-niyyât adlı eserleri verilebilir. Ahmed Çelebi, risalesinin başında şöyle demektedir (Ahatlı ve Korkmazer, 2018, s. 14):

Buhârî ve Meṣâbîh'in başında yer alan niyet hadisi pek çok nükte, mana ve sırları kapsar.

Onu hayırl1-şerli herkesin bilmesi gerekir. Çünkü tâât ve ibadet türleri onunla gerçekleşir ve mâsiyet ve kötülüğün kemâli onunla artar. $\mathrm{O}$, hayır ve şer bütün işlerin başıdır. $\mathrm{Bu}$ nedenle hadis kitapları bu hadisle başlar ve eski ve yeni şârihler onu araştırırlar.

Burada Ahmed Çelebi, niyet hadisinin önemini bariz bir şekilde gözler önüne sermektedir. Ahmed Çelebi'nin cümlelerindeki "eski ve yeni şârihler onu araştırırlar" ibaresine de özellikle dikkat edilmelidir. Bu ibare, niyet hadisinin yüzyıllar boyunca sürekli bir şekilde şerh edilmesinin sebebinin bu hadise verilen önem olduğunu açıça belirtmektedir. Bir önceki kısımda da zikredildiği üzere, niyet hadisi, üzerine en çok tek hadis şerhi yazılan hadistir.

Mevzubahis sebeple yazılan bir başka şerh de Muhammed b. Ahmed es-Seffârînî'nin (ö. 1188/1774) Netâicü'l-efkâr fî şerhi hadîși seyyidi'l-istiggfâr adlı eseridir. Bu kitapta Seffârînî, Hz. Peygamber'in "seyyidü'l-istiğfâr," yani “istiğfarların efendisi/en güzeli” olarak nitelediği bir duasını şerh etmiştir. Eseri neden yazdığını şöyle açıklamaktadır (es-Seffârînî, 1996, s. 79):

Aklıma "istiğfarların efendisi hadisi”ni şerh etmek geldi. Çünkü bu hadiste birçok fayda vardır, fakat bu faydalar belki bu duayı eden insanların çoğunun aklına gelmez. Bu dua öyle faydalarla ve sırlarla doludur ki Hz. Peygamber bu duayı istiğfarların efendisi seçmiştir. 
Anlaşılan o ki Seffârînî, bu hadisin çok faydalı olduğunu ve bu hadisi ve bu hadisten çıkan faydaları herkesin bilmesi gerektiğini düşünmüş, şerhi de bu yüzden yazmıştır.

Toplumdaki tartışmalar. Bir dönemin toplumunda vukû bulan ilmî tartışmalar, o dönemde verilen ilmî mahsulleri de etkilemiştir. Toplumda bir tartışma meydana geldiğinde, âlimler o tartışmaya taraf olmaktan ve doğru olduğunu düşündükleri görüşü desteklemekten geri durmamışlardır. Hatta bazen bu tartışmalar çok alevlenmiş, kimi âlimlerin yaşadıkları şehirleri terk etmelerine bile sebep olmuştur. Bu meyanda Muhammed b. Yahyâ ez-Zühlî (ö. 258/872) ile İmam Buhârî arasında vuku bulan halku'l-Kur'ân konusundaki tartışma hatırlanabilir (el-A'zamî, 1992, s. 369).

Erken dönem İslam toplumunda ehl-i hadis ile ehl-i rey -yahut muhaddisler ile fakihler- arasında vukû bulan tartışmalar meşhurdur. Fakihler, ehl-i hadisi, hadisleri anlamadan sadece rivayet etmek ile yetinmekle itham ederken; ehl-i hadis de fakihleri, sıhhat şartlarını taşımayan hadisleri, o hadisler sadece kendi imamlarından geldiği için kabul etmekle suçluyorlardı (el-Hattâbî, 1932, ss. 3-5). İşte bu tartışmalar, İbnü’1Kâss'ın (ö. 335/946) tek hadis şerhi literatürünün en erken örneklerinden biri olan Cüz 'ün fîhi fevâidü hadîsi Eb̂̀ 'Umeyr adlı eserini telif etmesine sebep olmuştur. Müellifin, eserinin mukaddimesinde belirttiğine göre o dönemde yaşayan kimi insanlar (büyük ihtimalle ehl-i rey fakihler) muhaddisleri gereksiz rivâyetlerin taşıyıcılığını yapmakla itham edip onları aşağılıyorlardı (İbnü'l-Kâss, 1992, s. 13). Müellif de bunun üzerine Ebû Umeyr hadisi (el-Buhârî, 2017, s. 1476) gibi ilk bakışta sadece Hz. Peygamber'in günlük hayatından bir kesit gibi görünen ve fikhî faydalardan hâlî olduğu düşünülen bir hadisten bile altmıştan fazla fikhî hüküm çıkarılabileceğini ve muhaddislerin rivayet ettikleri hadislerin gereksiz olmadığını göstermek amacıyla mezkûr eserini telif etmiştir.

Hadisin zahirinin müşkil olması. Tek hadis şerhlerinin telif sebeplerinden biri de bazı hadislerin zahirinin müşkil olmasıdır. Bazı hadislerde Allah'a, hakkında imkânsız olan ve tecsîme delalet eden sıfatlar izâfe edilmiştir. Allah'a mekân, parmak, el, yüz gibi sıfatlar izâfe eden bu hadisler İslâmî ilimlerde uzman olmayan insanlar tarafindan zahirî manasında anlaşılabileceğinden dolayı kelam âlimleri kadar hadis âlimleri de bu hadisler konusunda insanları uyarmayı ve bu hadislerin nasıl anlaşılacağı konusunda onları bilgilendirmeyi bir görev addetmişlerdir.

Zahiri müşkil olan bu tür hadislerden biri de "sübühât ve hicâb hadisi"dir (Müslim, 2006, s. 96). Hadiste Allah'ın "hicâb"ının nurdan olduğu, eğer bu "hicâb"1 açsaydı, “yüz”ünün "sübühât”ının ona bakan herkesi yakacağı geçmektedir. Bu hadisteki bazı kelimeler ilk bakışta yanlış anlaşılabileceğinden Ebû Bekir İbnü'l-Arabî (ö. 543/1148), hadiste geçen "sübühât”, "hicâb” ve "yüz” gibi kelimelerin nasıl anlaşılması gerektiğini açıklamak için Risâletün fi'l-kelâmi 'alâ müşkili hadîsis's-sübühâti ve'l-hicâb adlı eserini telif etmiştir (İbnü'l-Arabî, 2019, ss. 25-30). 
Reddiye yazma. Anlaşılması zor bazı hadislerin yorumlanması konusunda tarih boyunca âlimler arasında ihtilaflar meydana geldiği gibi, hadislerin sıhhati konusundaki hüküm de ictihâdî bir hüküm olduğundan, bu konuda da âlimler arasında ihtilaf vaki olmuştur. Böyle durumlarda âlimler, muhalefet ettikleri kişilere reddiye bâbında eserler telif etmişlerdir.

Hem yorumlama hem sshhat konusunda bir reddiye özelliği taşıyan eserlerden biri, Abdullah ed-Düveyş'in Difâ'u ehli's-sünne ve'l-îmân 'an hadîsi haleka Âdeme 'alâ șurati'r-Raḥmân adlı eseridir. Düveyş, bu eserini Nâsırüddin el-Elbânî'nin, Hz. Âdem'in yaratılmasıyla ilgili hadisin zayıf ve ehl-i sünnet akâidine aykırı olduğunu söylemesine itiraz etmek için yazmış, eserinde söz konusu hadisin sahih ve ehl-i sünnet akâidine uygun olduğunu savunmuştur (ed-Düveyş, ss. 4-5).

Yukarıdaki duruma benzer şekilde Ebû İshâk el-Huveynî, Der'ü'l- 'abes 'an hadîși izzâ belega'l-mâu kulleteyni lem yahmili'l-h̆abes adlı eserinde, Zâhid el-Kevserî'nin kulleteyn hadisini sadece mütesâhil âlimlerin tashih ettiğine dair iddiasını reddetmiş ve hadisin sahih olduğunu ispatlamaya çalışmıştır (el-Atîk, 1997, s. 14).

Hadisin sıhhat derecesini beyân etme. Hicrî ilk asrın son çeyreğinden itibaren, Hz. Peygamber ile bağı oldukça zayıf olan veya onunla hiçbir bağı bulunmayan bazı zayıf ve mevzu hadisler, çeşitli sebeplerden dolayı halk arasında intişâr etmiş ve bu sözler halk tarafindan sanki Hz. Peygamber'e aidiyeti kesinmiş gibi benimsenmiştir. Muhaddisler de halk arasında yaygınlaşan bu sözleri tahlil edip Hz. Peygamber'e ait olmayanları ona ait olanlardan ayırmayı kendilerine bir vecibe telakki etmişlerdir. Halk arasında yaygın olan sözleri inceleyen bu literatürün en meşhur iki örneği Şemseddin es-Sehâvî'nin el-

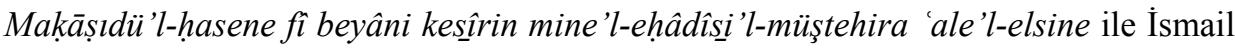
el-Aclûnî'nin (ö. 1162/1749) Keş̧ü'l-ḩafâ' ve müzîlü'l-ilbâs 'amme'ştehera mine'lehâadîs 'alâ elsineti'n-nâs adlı eserleridir.

Zikredilen eserler, halk arasında yaygın olarak kullanılan birçok sözü inceleyip bu sözlerin Hz. Peygamber'e ait olup olmadığını ve aitlerse sıhhat derecelerini kısa bir şekilde açıklarken, kimi müellifler bu sözlerden bazılarını tek tek ele alıp onların durumlarını ayrıntılı bir şekilde incelemişlerdir. Böylece ortaya tek hadis şerhi kategorisine dâhil edilebilecek eserler çıkmıştır. Bu tür kitaplara güzel bir örnek Selîm

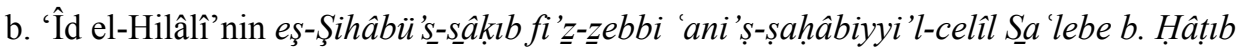
adlı eseridir. Hilâlî, bu eserinde Salebe b. Hâtı hakkında vârid olan ve onu zemmeden bir hadisin sahih olmadığını ve bu hadisin rivayet edilmesiyle bu sahâbîye büyük bir iftira atıldığını, hadisin rivâyet ve muhteva açısından illetlerini açığa çıkararak ispatlamaya çalışmıştır. Kendisi, kitabın mukaddimesinde bu şerhi telif ediş sebebini şöyle açıklamıştır (el-Hilâlî, 2004, s. 6):

Beni bu kitabı yazmaya iten sebepler şunlardır: Birincisi, bu hadis, tefsir kitaplarında çokça rivâyet edilmiştir, ancak onun fesâdına ve nekâretine müfessirlerin çoğu dikkat 
çekmemiştir. İkincisi, davet ve irşad alanında faaliyet gösterenler bu hadisi sahih zannedip sıkça kullanmışlardır, bu da hadisin halk arasında yaygınlaşmasına sebep olmuştur. Üçüncüsü, bu hadis Bedir Gazvesi'ne iştirak etmiş bir sahâbîye münafıklık ithamında bulunmaktadır.

Görüldüğü üzere müellifi kitabı yazmaya teşvik eden şey, halk arasında hadis zannedilen bir sözün Hz. Peygamber'e ait olmadığını açıklamaktır.

Çelişir gibi gözüken hadislerin arasını telif etme. Devasa bir hacme sahip olan hadis külliyâtındaki bazı hadisler ilk bakışta birbiriyle çelişiyormuş gibi gözükebilir, ancak hadislerin hepsinin kaynağı Hz. Peygamber olduğundan hadislerin gerçekten çelişmesi imkânsızdır. Bu sebepten, tarih boyunca hem muhaddisler hem de fakihler birbiriyle çelişir gibi gözüken hadislerin aslında çelişmediğini ispatlama çabasıyla birçok eser telif etmişlerdir. Öyle ki bu çabalar sonucunda "muhtelifü'l-hadîs" adında, birbirleriyle çelişir gibi görünen hadisleri inceleyen ve aralarını bulma amacını taşıyan müstakil bir ilim dalı teşekkül etmiştir. Bu ilim dalında verilen eserlerin en meşhuru şüphesiz İbn Kuteybe'nin (ö. 276/889) Te 'vîlü muhtelifi'l-hadîs isimli eseridir.

Birbiriyle ihtilaf halindeymiş gibi gözüken bazı hadisler ise tek başlarına müstakil eserlerde incelenmişlerdir. Şihâbeddin el-Hafâcî'nin Risâle fi hadîsi rufi 'a 'l-kalemu 'an selâse ve't-tevfik beynehû ve beyne'l-hadîsil'l-vârid fi'ṣ-șıbyân murûhum bihâ liseb in adlı eseri buna bir örnek sayılabilir. İsminden de anlaşılabileceği üzere bu risale, içinde çocukların da olduğu üç grup insandan günahın kaldırıldığını (ve dolayısıyla bunların mükellef olmadıklarını) söyleyen hadis ile çocuklara namazın yedi yaşına geldiklerinde (yani daha mükellef olmamış iken) emredilmesi hakkındaki hadisi telif etme çabasıdır (el-Atîk, 1997, s. 87).

Muhammed b. el-Basrî'nin de bu amaçla yazılmış bir eseri vardır. Tenbîhü'l-ḥuyârâ ve tezkiratü'l-mehera fi'l-cem 'i beyne ehâdîsi'l-firâr ve'n-nehy ve lâ 'advâ ve lâ tıyera adlı eserinde müellif, bulaşıcı hastalığa yakalanan kişilerden kaçılmasını emreden hadisler ile bulaşıcı hastalığın varlığını inkâr eden hadisleri uzlaştırmaya çalışmıştır (el-Atîk, 1997, s. 178).

Yeni yöntem arayışları. 14./20. ve 15./21. yüzyıllarda insanlığın ilmî mirasına eklenen bilimsel gelişmeler, toplumsal olguların anlaşılması konusunda bir devrim meydana getirdi. $\mathrm{Bu}$ gelişmeler neticesinde ortaya çıkan yeni sosyal bilimlerin yöntemleri, eski yöntemlerin terk edilmesine yol açtı. Bununla beraber, özellikle içtimai ilimler söz konusu olduğunda, hiçbir ilmin diğerlerinden bağımsız bir şekilde mükemmele yakın sonuçlar doğuramayacağı anlaşıldı ve belirli bir konu incelenirken birçok ilim dalının yardımına başvurulmasının gerekliliği benimsendi. Buna "disiplinler-arasılık" adı verildi. Aslında -hadis ile fikıh ilimleri arasındaki geçişkenlikte de görülebileceği üzere- bu "ilimler arası yardımlaşma" mefhumuna, İslam tarihinde İslâmî ilimlerin teşekkül sürecinin en başından beri rastlanabilmektedir. Ancak, içinde bulunduğumuz 
yüzyılda söz konusu olan yeni olgu, İslâmî ilimlerin meseleleri incelenirken, genellikle Avrupa ve Amerika gibi İslam kültürüne yabancı toplumlarda neşet etmiş olan sosyal bilimlerin yardımına başvurulmasıdır. Bu kısımda, sosyal bilimlerle hadis ilminin yardımlaşması gerektiği düşüncesinin bazı sonuçları görülecektir.

Kimi araştırmacılar, modern öncesi dönemde telif edilen hadis şerhlerinde hadisleri anlama ve yorumlama konusunda kullanılan yöntemlerle birlikte (ya da onların yerine) yeni metotlardan istifade edilmesi gerektiğini ve sosyal bilimlerin metotlarının buna uygun olduğunu düşünmüşlerdir. Bu metotların hadisleri anlama ve yorumlamada kullanılabileceğini ispatlamak amacıyla da belirli hadisleri seçerek söz konusu metotları bu hadisleri şerh etmede kullanmışlardır. Böylece bu çalışmanın kapsamına giren tek hadis şerhi türü eserler ortaya çıkmıştır.

Disiplinler-arası hadis şerhi çalışmalarına ilk olarak Mustafa Işık'ın, hadisleri, iletişim fakültelerinde öğretilen $5 \mathrm{~N} 1 \mathrm{~K}$ habercilik yöntemi ile şerh etmeye çalışması örnek olarak verilebilir. Işık (2017), "Toplum Gemisi Hadisinin Sübut ve Anlama Çalışması” adlı makalesinde, "toplum gemisi hadisi" adını verdiği hadise $5 \mathrm{~N} 1 \mathrm{~K}$ olarak formüle edilen "ne", "neden", "nasıl”, "nerede", "ne zaman" ve "kim" sorularını sormuş ve hadisi bu sorulara verdiği cevaplarla şerh etmeye çalışmıştır. Açıkçası, yazar her ne kadar bu makalesinde yeni bir yöntem ortaya koymuş gibi gözükse de, hadislere "ne", "neden", "nasıl", "nerede", "ne zaman" ve "kim" sorularının sorulması yeni bir uygulama değildir; klasik dönemde telif edilen şerhlerde de hadislere bu sorular sorulmuştur. Işık'ın bu çalışmalarda yaptığı tek yeni şey, bu soruları sorduğunu açıkça söyleyip soruları başlıklara taşımasıdır. Bundan dolayı bu yöntem denemesi çok da orijinal ve başarılı gözükmemektedir. Ayrıca, yazarın yeni bir hadis şerhi yöntemi uygulamadaki başarısızlığı, makalesinde akademik yazım ve kaynak kullanma yöntemlerini uygulama konusunda da kendisini göstermektedir. Kaynak değeri olmayan birçok internet sitesini referans gösteren yazar, böyle yaparak çalışmasının kıymetini düşürmüştür. Örneğin yazar, http://tr.wikipedia.org ve hatta http://eksisozluk.com gibi internet erişimi olan herkesin katkıda bulunabildiği, dolayısıyla da yanlış bilgilerin bulunmasının muhtemel olduğu internet sitelerinden alıntılar yapmıştır (ss. 75 ve 94). Işık (2018), bu yöntemi daha ayrıntılı bir şekilde açıklamak amacıyla Hadisleri Anlama Yöntemi -5NIK'dan Hareketle- adlı bir kitap da yazmıştır.

Nihat Yatkın (2013) da Hadisi Anlamada Yöntem adlı kitabında "ilmin dev adımlarla geliştiği çağımızda" çağın ilmî seviyesine uygun yeni hadis şerhlerine ihtiyaç olduğunu vurgulamıştır (s. 18). Ardından, seçtiği bir hadisi sosyoloji ve psikoloji disiplinlerinin metot ve verilerinden faydalanarak şerh etmeye çalışmıştır.

Hadisleri anlama ve yorumlama konusunda sosyal bilimlerin yanında pozitif bilimlerin ve hermenötiğin kullanımı da tartışlan konular arasındadır. Muhammed Enes Topgül (2011), "Paradigmadan Paradigmaya: Pozitif Bilim Neden Metin Tenkit Kriteri Olsun?”, Osman Oruçhan (2015), “Bazı Hadisleri Anlama ve Yorumlamada 
Bilimsel Verilerin Kullanımı" ve Fikret Karapınar (2016), "Hadisi Anlama ve Yorumlamada Hermeneutik Bir Yorum Yöntemi Olabilir Mi?” adlı makalelerinde bu konuyu işlemişlerdir. Kanaatimizce, pozitif ve sosyal bilimlerin metotlarının hadislerin anlaşılmasında kullanılması ihtiyatla yaklaşılması gereken bir düşüncedir. Bütün bu bilimler, Müslümanların toplumsal kodlarından farklı kodlara sahip toplumlarda neşet etmiştir ve o toplumları anlayıp onların problemlerine çözüm bulmak için geliştirilmiştir; bundan dolayı da İslâmî ilimlerin ön kabullerinden çok farklı ön kabullere sahiptir. Bu bilimlerin metotlarını, Müslüman toplumların yaşayış tarzının kaynağı olan hadisleri anlamada kullanmak, birçok derecede ontolojik bir bunalıma sebebiyet verebilir.

Şahsî sebepler. Bütün bu sebeplerle telif edilmiş tek hadis şerhlerinin yanında, genel bir kategoriye sokulamayacak şahsî birtakım sebeplerle telif edilmiş tek hadis şerhleri de vardır. Bu şerhlerin telifinde, müelliflerin başına gelen olaylar etkili olmuştur.

İmam Nevevî'nin el-Erba'ûne'n-Neveviyye adlı kırk hadis derlemesi, kırk hadis kitaplarının en meşhurudur. Tarih boyunca birçok âlim bu esere şerh yazmıştır. Az bilinen hususlardan biri ise, aslında Nevevî'nin kendisinin de bu eserini şerh etmeye başladığıdır. Nevevî, bu eserine bir şerh yazmaya başlamış, ancak yalnızca bir hadisi şerh ettikten sonra vefat etmiş, eserin tamamını şerh etmeye ömrü yetmemiştir (enNevevî, 2015, s. 33). Böylece ortaya bir tek hadis şerhi çıkmıştır. Müellifin, eserinin ilk hadisi olan niyet hadisini bir imla meclisinde şerh etmesi sebebiyle bu eser, el-imlâ' şerḥu hadîsîi inneme'l-a 'mâlu bi’n-niyyât olarak isimlendirilmiştir.

Şahsî sebeplerden dolayı telif edilen tek hadis şerhlerine bir başka örnek de Osman el-Ankaravî'nin (ö. 1277/1860) Füyûżu'l-me 'ârifi'l-ilâhiyye fî şerḥi hadîsi inna'llâhe yühibbü'l- 'abde't-takiyye'l-ganiyye'l-hafiyye adlı şerhidir. Eserin mukaddimesinde geçtiğine göre dönemin sultanı, şerhin isminde geçen hadisi hüsn-i hatla yazıp, altın varaklı bir çerçeveye koydurup Ankaravî'ye hediye etmiştir. Ankaravî de bunun üzerine bu hadisi şerh etmiştir (el-Atîk, 1997, ss. 44-45).

\section{Sonuç}

Sonuç olarak, genelde hadis şerhlerinin, özelde tek hadis şerhlerinin günümüze dek yeterince çalışılmadığını söylemek mümkün gözüküyor. Hadis şerhinin müstakil bir ilim olarak kabul edilip edilemeyeceği konusundaki tartışmalar ve hadis şerhlerinin tarihinin yazımında görülen aksaklıklar, bu alanın daha yoğun ve detaylı bir şekilde çalışılması gerektiğinin en açık delillerini teşkil etmektedir. Tek hadis şerhlerinin ihmal edilmişliğine ise hakkında yapılan çalışmaların nitelik olarak eksik ve nicelik olarak az olması işaret etmektedir.

Hadis şerhlerinin ve tek hadis şerhlerinin çalışılma oranıyla literatürünün genişliği bir ters orantı arz etmektedir. Zira hadis şerhleri çok geniş bir literatüre sahiptir ve 
tek hadis şerhlerinin de ondan geriye kalır bir yanı yoktur, buna rağmen bu literatür hakkında çok az çalışma yapılmıştır.

Tek hadis şerhleri hakkında üç müstakil çalışma kaleme alınmıştır. Bu çalışmaların hepsi de bibliyografik bir mahiyet arz etmektedir, bundan dolayı bu çalışmalarda tek hadis şerhlerinin tarihi ve telif sebepleri hakkında malumata rast gelmek pek mümkün gözükmemektedir. Bu da tek hadis şerhlerinin tarihinin nitelikli bir şekilde yazılmasını güçleştirmektedir. Bununla beraber, tek hadis şerhlerinin sayısındaki belirli dönemlerdeki artış ve eksilişler üzerinden bu şerhlerin tarihine dair yüzeysel de olsa bir fikir edinmek mümkün olmuştur.

Tek hadis şerhleri çok çeşitli sebeplerle yazılmıştır. Bir çalışmada ihâta edilmesi oldukça zor gözüken bu sebepler, aynı zamanda İslâmî ilimlerin tarihi ve İslâmî ilimler külliyatının oluşumuyla ilgili ipuçları da ihtiva etmektedir. Daha detaylı bir çalışmada çok farklı sebepler tespit edilip Müslümanların ilim ve kültür tarihinin karanlık sayfaları aydinlatılabilir.

\section{Teşekkür}

Danışman hocam Halit Özkan'a makalenin bütün aşamalarındaki kıymetli katkılarından ve mütemâdî desteklerinden dolayı teşekkürlerimi sunarım.

\section{Kaynakça}

Ahatl1, E. \& Korkmazer, G. (2018). Osmanlı hadis şerhçiliğinde niyet hadisi örneği. Usûl: İslam Araştırmaları, 29, 7-38.

Akay, T. R. (2019). Osmanlı'da Tek Hadis Şerhçiliği: Kâfiyecî (879/1474) Örneği (Yüksek lisans tezi, İstanbul Üniversitesi, Sosyal Bilimler Enstitüsü, İstanbul).

el-Askalânî, A. (2015). Cüz'ün fi'l-kelâmi 'alâ kavlihî inne'mraetî lâ teruddü yede lâmis. (Cemâl el-Hecresî, Nşr.) Beyrût: Dâru'l-Beşâiri'l-İslâmiyye.

el-Atîk, Y. (1997). et-Ta 'rîf bimâ üfride mine'l-ehâdîsi bi 't-tasnîf. Riyâd: Dâru's-Sumey'î.

el-A‘zamî, M. M. (1992). Buhârî, Muhammed b. İsmâil. DİA, VI, 368-372.

Bâzmûl, M. (2009). İlmü şerhi'l-hadîs ve ravâfidü'l-bahsi fîhi. Mekke: Mahedü'l-Buhûsi'l-İlmiyye.

Blecher, J. (2018). Hadīth commentary. In: Encyclopaedia of Islam, THREE, Edited by: Kate Fleet, Gudrun Krämer, Denis Matringe, John Nawas, Everett Rowson. Consulted online on 02 November 2019 http://dx.doi.org/10.1163/1573-3912_ei3_COM_32080

el-Buhârî, M. (2017). Sahîhu'l-Buhârî. (Mervân Da‘bûl, Nşr.) Dimeşk: Müessesetü’r-Risâle Nâşirûn. 
Ceyhan, A. (1991). Sırat-ı Müstakim ve Sebilürreşâd Mecmuaları Fihristi. Ankara: Diyanet İşleri Başkanlığı Yayınları.

Cihan, S. (1977). Osmanlı devrinde Türk hadisçileri tarafından kırk hadis dışında muayyen sayıda derlenen hadis mecmuaları ve bir hadis üzerine yazılan risaleler. Atatürk Üniversitesi İslâmî İlimler Fakültesi Dergisi, 2, 157-173.

Çakan, İ. L. (2015). Hadis Edebiyatı. İstanbul: Marmara Üniversitesi İlahiyat Fakültesi Vakfi Yayınları.

ed-Düveyş, A. (t.y.) Difâ 'u ehli s-sünne ve'l-îmân 'an hadîsi haleka Âdeme 'alâ sûrati'r-Rahmân. (Abdülazîz el-Müşeykah, Nşr.) Dâru'l-Ulyân.

Efendioğlu, M. (2010). Şerh (Hadis). DiA, XXXVIII, 559-560.

el-Hattâbî, H. (1932). Me ‘âlimü’s-sünen. (Muhammed Râğı et-Tabbâh, Nşr.) Haleb: y.y.

el-Hilâlî, S. (2004). eş-Şihâbü 's-sâkıb fi'z-zebbi 'ani sahâbiyyi'l-celîl Sa 'lebe b. Hâtıb. Ammân: ed-Dâru'l-Eseriyye.

Işı1k, M. (2017). Toplum gemisi hadisinin sübut ve anlama çalışması. Inönü Üniversitesi Ilahiyat Fakültesi Dergisi, 8/1, 73-104.

Işık, M. (2018). Hadisleri Anlama Yöntemi -5N1K'dan Hareketle-. Ankara: Fecr Yayınevi.

İbn Teymiyye. (1993). Su'âlün fỉ hadîsi'n-nüzûl ve cevâbuhu. (Muhammed el-Hamîs, Nşr.) Riyâd: Dâru'l-Âsime.

İbnü'l-Arabî. (2019). Risâletün fi'l-kelâmi 'alâ müşkili hadîsi's-sübühâti ve'l-hicâb. (Yûnus Bekayân, Nşr.) Tanca: Dâru'l-Hadîsi'l-Kettâniyye.

İbnü'l-Esîr, M. (1969). Câmi ‘u'l-usûl fì ehâdîsi'r-rasûl. (Abdülkâdir el-Arnâût, Nşr.) Mektebetü'lHalvânî.

İbnü'l-Kâss. (1992). Cüz'ün fîhi fevâidü hadîsi Ebî 'Umeyr. (Sâbir Ahmed el-Batâvâ, Nşr.) Kâhire: Mektebetü's-Sünne.

el-Kannevcî, S. (1978). Ebcedü'l- ‘ulûm. (Abdülcebbâr Zekâr, Nşr.) Dimeşk: Menşûratü Vizârati’sSekâfe ve'l-İ́şâdi'l-Kavmî.

el-Kannevcî, S. (t.y.) el-Hitta fí zikri's-sthâhi ’s-sitte. (Alî Hasen el-Halebî, Nşr.) Beyrût: Dâru'l-Cîl. Kadı İyâz. (1975). Buğyetü'r-râid limâ tezammenehû hadîü̈ Ümmi Zer 'mine'l-fevâid. (Salâhuddîn el-İdlibî, Nşr.) Fas: Vizâratü'l-Evkâf ve'ş-Şuûni'l-İslâmiyye.

Kallek, C. (1999). İbn Receb. DİA, XX, 243-47.

Kandemir, M. Y. (1996). Garîbü'l-Hadîs. DİA, XIII, 376-378.

Karapınar, F. (2016). Hadisi anlama ve yorumlamada hermeneutik bir yorum yöntemi olabilir mi? Uluslararası Dini Araştırmalar ve Küresel Barış Sempozyumu, 17-18 Mayıs 2013, Konya, 1, 363-375.

Kaynar, E. (2016). Buhârî'nin bâb başlıklarlyla ilgili çalışmalar ve bâb başlıklarındaki kendi ifadelerinin değerlendirilmesi (Yüksek lisans tezi, İstanbul 29 Mayıs Üniversitesi, Sosyal Bilimler Enstitüsü, İstanbul).

Kemâleddin İbnü'l-Hümâm. (2011). İ'râbu kavlihî kelimetâni hafífetâni 'ale’l-lisân. (Kahtân edDevrî, Nşr.) Beyrût: Kitâb Nâşirûn. 
Kettânî, M. (1994). Hadis Literatürü. (Yusuf Özbek, Çev.) İstanbul: İz Yayıncılık.

Müslim b. el-Haccâc. (2006) Sahîhu Müslim. (Muhammed el-Fâryâbî, Nşr.) Riyâd: Dâru Taybe.

en-Nevevî, Y. (2015). el-İmlâ' şerhu hadîsi inneme 'l-a 'mâlu bi'n-niyyât. (Muhammed el-Cûrânî, Nşr.) Tanca: Dâru'l-Hadîsi'l-Kettâniyye.

Oruçhan, O. (2015). Bazı hadisleri anlama ve yorumlamada bilimsel verilerin kullanımı. Pamukkale Üniversitesi İlahiyat Fakültesi Dergisi, 2/4, 40-72.

Sandıkçı, K. (1991). İlk Ü̧̧ Asırda İslâm Coğrafyasında Hadîs. Ankara: Diyanet İşleri Başkanlığı Yayınları.

es-Seffârînî, A. (1996). Netâicü 'l-efkâr fî şerhi hadîsi seyyidi'l-istiğfâr. (Abdülazîz ed-Dehîl, Nşr.) Riyâd: Dâru's-Sumey‘î.

es-Süyûtî, C. (1998). Müntehe'l-âmâl fỉ şerhi hadîsi inneme'l-a 'mâl. (Muhammed Atıyye, Nşr.) Beyrût: Dâru İbn Hazm.

Topaloğlu, N. (1998). Tek Hadis Şerhleri. İzmir: Anadolu Matbaacılık.

Topgül, M. E. (2011). Paradigmadan paradigmaya: pozitif bilim neden metin tenkit kriteri olsun? Hadis Tetkikleri Dergisi, 9/2, 117-141.

Türcan, Z. (2011). Hadis Şerh Geleneği: Doğuşu, Gelişimi ve Dönüşümü. Ankara: Türkiye Diyanet Vakfi Yayınları.

Uğur, M. (1996). Hadis İlimleri Edebiyatı. Ankara: Türkiye Diyanet Vakfı Yayınları.

Ünver, İ. (1986). Mesnevi. Türk Dili: Türk Şiiri Özel Sayısı II: Divan Şiiri, 415-416-417, 430-563.

Yatkın, N. (2013). Hadisi Anlamada Yöntem. İstanbul: Marmara Üniversitesi İlahiyat Fakültesi Vakfi Yayınları. 